\title{
Pengetahuan Perawat Mengenai Budaya Dalam Lingkup Kerja Perawat untuk Meningkatkan Keselamatan Pasien
}

\author{
Dea Kristin Sania Manik \\ Deakristin01@gmail.com
}

\section{LATAR BELAKANG}

Rumah sakit adalah sarana pelayanan kesehatan yang dibutuhkan ketika seseorang sakit dan membutuhkan bantuan dengan tujuan untuk menyelamatkan kondisi pasien. Dengan berlalunya waktu dan perkembangan ilmu pengetahuan dan teknologi rumah sakit tidak hanya menjadi tempat untuk menyelamatkan pasien. Berbagai layanan dapat diakses oleh pasien yang membutuhkan bantuan. Pasien yang memerlukan bantuan menyeluruh dan intensif selama 24 jam dapat mengakses layanan rawat inap. Perawatan rawat inap memiliki peran penting dalam pelayanan perawatan untuk observasi, diagnosis, pengobatan atau upaya perawatan kesehatan lainnya. Keselamatan pasien di rumah sakit melibatkan partisipasi dari semua petugas kesehatan, terutama perawat. Perawat sebagai salah satu tenaga kesehatan yang mempunyai jumlah cukup dominan di rumah sakit yaitu sebesar 50 sampai $60 \%$ dari jumlah tenaga kesehatan yang ada. Pelayanan asuhan keperawatan yang diberikan kepada pasien merupakan pelayanan yang terintegrasi dari pelayanan kesehatan yang lainnya dan memiliki peran yang cukup penting bagi terwujudnya kesehatan dan keselamatan pasien.

Budaya keselamatan pasien adalah pola terpadu perilaku individu dan organisasi dalam memberikan pelayanan yang aman dan bebas dari cedera. Budaya keselamatan adalah output dari individu dan kelompok terhadap nilai-nilai, sikap, kompetensi, dan pola dan kebiasaan yang mencerminkan komitmen dan gaya dan kemampuan organisasi dan manajemen keselamatan kesehatan. Budaya keselamatan pasien merupakan suatu hal yang pentingkarena membangun budaya keselamatan pasien merupakan suatu cara untukmembangun program keselamatan pasien secara keseluruhan, karena apabila kita lebih fokus pada budaya keselamatan pasien maka akan lebih menghasilkan hasil keselamatan yang lebih apabila dibandingkan hanya menfokuskan pada programnya saja.

Teori Reason menyatakan bahwa insiden keselamatan pasien disebabkan oleh dua faktor, kesalahan laten dan kesalahan aktif. Kesalahan laten terkait dengan insiden keselamatan pasien meliputi lingkungan eksternal, manajemen, lingkungan sosial atau organisasi, lingkungan fisik, interaksi antara manusia dan sistem. Budaya keselamatan adalah bagian dari kesalahan laten yang terkait dengan manajemen, sedangkan indikator budaya keselamatan meliputi kerja sama, 
komunikasi, kepemimpinan, pelaporan dan respon terhadap kesalahan tidak menghukum. Kunci pencegahan cedera dalam pelayanan keperawatan adalah identifikasi risiko.

\section{KATA KUNCI : Pengetahuan, Perawat, Budaya, Keselamatan Pasien}

\section{METODE PENELITIAN}

Penulisan ini dilakukan dengan metode kajian bebas terhadap pokok bahasan yang di kumpulkan dari beberapa sumber yang berkaitan dengan pokok bahasan, seperti jurnal online maupun jurnal print, dan buku online.

Setelah membaca beberapa jurnal dan menyeleksinya penulis menentukan 10 jurnal yang dipilih.

Alasan jurnal yang di pilih diantaranya :
a. Sumbernya jelas
b. Sesuai dengan topik yang diinginkan
c. Batas tahun diterbitkannya artikel tidak lebih dari 10 tahun

\section{HASIL PENELITIAN}

Pengukuran budaya keselamatan pasien dipengaruhi oleh sikap aman dan tidak aman pegawai di level individu, unit kerja dan organisasi. Secara khi.rsus di level manajemen senior dalam hal kepemimpinan transformasional yang berbagai penelitian tentang budaya menunjukkan bahwa kepemimpinan transformasional sangat berpengaruh dalam membangun suatu budaya: Untuk mengukur kondisi iklim keselamatan pasien $\mathrm{Ci}$ rumah sakit mencakup 4 hal yang terkait, yaitu kepemimpinan transforrrasional (di tingkat CEO/direksi RS), kerjasama tim (di tingkat unit kerja), kesadaran individual (di tingkat individu) serta iklim keselamatan pasien (di tingkat organisasi/ RS).3 Saat ini terjadi penurunan kualitas pelayanan kesehatan yang menyebabkan terjadinya penurunan upaya keselamatan dalam. Keperawatan hampir disemua Negara.

Penerapan budaya keselamatan pasien dalam sebuah organisasi tidak terlepas dari peran aktif atasan (supervisor atau manajer dalam mempromosikan dan melakukan tindakan-tindakan yang mendukung berjalannya proses penanaman nilai yang dianut masih banyak perawat yang menganggap tindakan supervisor / manajer dalam mempromosikan keselamatan pasien masih rendah, karena masih adanya perawat yang mengganggap bahwa Peran aktif manajer dalam menanamkan niiai-nilai keselamatan pasien bisa dibilang kurang maksimal. Penjelasan diatas bisa disimpulkan bahwa masaiah utama yang harus menjadi pricritas untuk diselesaikan adalah perawatan terhadap pasien yang tidak aman. Perlu ada Perubahan budaya didalam rumah sakit agar 
budaya keselamatan pasien semakin baik. Budaya keselamatan yang baik dapat mengurangi risiko terjadinya kejadian yang tidak diinginkan maka diperlukan pelatihan secara rutin bagi petugas medis agar benar-benar mernahami budaya keselamatan pasien, pengawasan dari atasan juga harus ditingkatkan sebagai salah satu upaya untut menerapkan budaya keselamatan pasien.

Budaya keselamatan pasien yang diharapkan di rumah sakit adalah budaya keselamatan positif yang ditandai dengan adanya alur informasi yang baik dan adanya proses komunikasi yang berkaitan dengan pembelajaran pada saat KTD, memiliki pemimpin yang komit dan eksekutif yang bertanggung jawab serta pendekatan untuk tidak menyalahkan dan tidak memberikan hukuman pada insiden yang dilaporkan. Hasil penelitian didukung oleh penelitian Nurmalia, (2013) tentang pengaruh program mentoring terhadap penerapan budaya keselamatan pasien didapat $52.2 \%$ perawat memiliki budaya keselamatan negatif. Budaya keselamatan pasien yang diharapkan di rumah sakit adalah budaya keselamatan positif yang ditandai dengan adanya alur informasi yang baik dan adanya proses komunikasi yang berkaitan dengan pembelajaran pada saat KTD, memiliki pemimpin yang komit dan eksekutif yang bertanggung jawab serta pendekatan untuk tidak menyalahkan dan tidak memberikan hukuman pada insiden yang dilaporkan. Hasil penelitian didukung oleh penelitian Nurmalia, (2013) tentang pengaruh program mentoring terhadap penerapan budaya keselamatan pasien didapat $52.2 \%$ perawat memiliki budaya keselamatan negatif. Penelitian Nivalinda (2013) tentang pengaruh motivasi perawat dan gaya kepemimpinan kepala ruangan terhadap penerapan budaya keselamatan pasien diperoleh hasil $51.4 \%$ perawat memiliki budaya keselamatan pasien negatif.

\section{PEMBAHASAN}

Keselamatan (safety) telah menjadi isu global termasuk juga untuk rumah sakit. Oleh karena itu, keselamatan pasien merupakan prioritas utama untuk dilaksanakan dan hal tersebut terkait dengan terjadinya Insiden Keselamatan Pasien (IKP) di rumah sakit. Menurut Depkes RI (2008) dalam Panduan Nasional Keselamatan Pasien Rumah Sakit, langkah pertama program keselamatan pasien di rumah sakit adalah membangun budaya keselamatan pasien atau menumbuhkan kesadaran pada seluruh karyawan akan pentingnya nilai keselamatan di rumah sakit. Jadi, Untuk meningkatkan mutu pelayanan keselamatan pasien di tingkat unit maka harus dilakukan upaya perubahan budaya keselamatan pasien di seluruh unit Rumah Sakit. Penelitian Brown \& Wolosin (2013) mencoba mengeksplorasi hubungan antara persepsi staf terhadap budaya keselamatan dan langkah-langkah yang sedang berlangsung di rumah sakit berdasarkan struktur unit keperawatan, proses perawatan, dan resiko yang merugikan pasien. Hubungan antara tindakan keperawatan, kinerja rumah sakit dan budaya keselamatan dieksplorasi di beberapa rumah sakit dan unit keperawatan. Persepsi budaya keselamatan diukur 6 bulan sebelum pengumpulan metrik keperawatan dan hubungan antara kedua data yang dieksplorasi menggunakan hubungan korelasional dan analisis regresi. Hubungan signifikan yang ditemukan 
adalah langkah-langkah proses untuk pencegahan jatuh. Beberapa asosiasi diidentifikasi dari budaya keselamatan dan struktur pemberian perawatan, seperti campuran keterampilan, pergantian staf, dan intensitas beban kerja menunjukkan hubungan yang signifikan dengan budaya keselamatan. Budaya keselamatan merupakan faktor penting untuk memahami upaya untuk memajukan perawatan pasien yang aman. Hasil ini memberikan implikasi kualitas pelayanan untuk kepemimpinan rumah sakit. Ketika para pemimpin memprioritaskan budaya keselamatan, resiko terhadap pasien mungkin telah diperbaiki dengan pergantian staf dan peningkatan produktivitas. Hal ini dapat dijadikan investasi dalam sistem keselamatan pasien untuk memberikan perawatan andal dan aman (Brown \& Wolosin, 2013).

Untuk meningkatkan budaya keselamatan pasien, kesadaran perawat tentang pentingnya keselamatan pasien juga perlu ditingkatkan. Penelitian yang dilakukan oleh Kim dkk (2013) yang bertujuan untuk mengidentifikasi faktorfaktor yang mempengaruhi persepsi pentingnya dan praktek manajemen keselamatan pasien antara karyawan rumah sakit di Korea. Penelitian ini dilakukan dengan menggunakan desain deskriptif dan laporan kuesioner. 280 karyawan direkrut dari 3 rumah sakit menggunakan metode convenience sampling. Hasil penelitian ini menunjukkan bahwa faktor yang mempengaruhi persepsi pentingnya manajemen keselamatan pasien adalah apakah karyawan rumah sakit kontak dengan pasien saat bertugas, jam kerja mingguan, pendidikan manajemen keselamatan pasien, dan sistem konstruksi manajemen keselamatan pasien. Faktor yang mempengaruhi praktek manajemen keselamatan pasien adalah beban kerja, dan sistem konstruksi manajemen keselamatan pasien Hasil ini menunjukkan kebutuhan untuk mengembangkan strategi untuk meningkatkan persepsi pentingnya konstruksi dan praktek konstruksi di antara semua karyawan rumah sakit (Kim, Park, Park, Yoo, \& Choi, 2013).

Menurut Gibson Variabel, organisasi mempunyai efek tidak langsung terhadap perilaku dan kinerja individu. Salah satu dari variabel organisasi adalah budaya organisasi. Budaya keselamatan pasien yang ada dirumah sakit memiliki hubungan langsung terhadap pelaksanaan pelayanan yang bertujuan untuk menjamin keselamatan pasienyang secara keseluruhan akan mempengaruhi kinerja individu dalam mengimplementasikan nilai-nilai yang mendukung keselamatan pasien. Keselamatan pasien dapat dilihat melalui indikator rendahnya angka insiden keselamatan pasien. Salah satu perilaku yang diharapkan dari individu adalah keterbukaan melaporkan terjadinya insiden.

Hasil penelitian ini menjawab hipotesis bahwa tidak terdapat hubungan yang bermakna antara pemberdayaan champion keselamatan pasien terhadap penerapan budaya keselamatan pasien. Keselamatan pasien yang berjalan di RS tempat penelitian masih bersifat reaktif terhadap insiden yang terjadi dan belum berkembang ke arah penataan sistem yang baik. Tingkat maturitas budaya keselamatan pasien berada pada kategori tingkat maturitas reaktif, yaitu organisasi hanya berpikir tentang keselamatan pasien setelah terjadi insiden (Ajeigbe, 2012). Penerapan budaya keselamatan pasien tidak terlepas dari pembentukan capacity building. 
Pembentukan kelompok kecil efektif dalam peningkatan capacity building budaya keselamatan pasien dan mampu menyediakan lingkungan yang baik dalam proses belajar (Fleming, 2005). Champion keselamatan pasien di rumah sakit tempat penelitian ditunjuk dari kepala ruangan. Hal ini diharapkan dapat lebih meningkatkan keterjangkauan program ke unit terkecil. Namun penunjukkan kepala ruangan sebagai champion meningkatkan beban kerja kepala ruangan yang sudah overload sehingga peran sebagai champion keselamatan pasien menjadi tidak optimal. Program pemberdayaan champion keselamatan pasien dilakukan dalam waktu sebulan. Pada kurun waktu tersebut telah terjadi peningkatan pada penerapan budaya keselamatan pasien. Apabila program tersebut terus dilaksanakan secara terus menerus dan berkesinambungan, diharapkan penerapan budaya keselamatan pasien dapat mengalami peningkatan yang lebih baik. Budaya KP merupakan nilai, kepercayaan, yang dianut bersama dan berkaitan dengan struktur organisasi, dan sistem pengawasan dan pengendalian untuk menghasilkan norma-norma perilaku (Ferguson \& Fakelman, 2005). Hal ini melibatkan persepsi individu tersebut. Staf dengan persepsi baik terhadap KP akan memudahkan penerapan budaya KP (Disch, et al., 2011).

Hasil penelitian ini memberikan informasi bahwa program pemberdayaan champion keselamatan pasien merupakan upaya positif dalam peningkatan penerapan budaya keselamatan pasien. Hal ini terlihat dari peningkatan penerapan budaya keselamatan pasien secara keseluruhan setelah dilaksanakannya program tersebut. Sebagian besar dimensi budaya keselamatan mengalami peningkatan setelah program pemberdayaan champion keselamatan pasien dilaksanakan, meskipun terdapat beberapa dimensi yang mengalami penurunan. Dimensidimensi pada budaya keselamatan pasien tersebut saling mempengaruhi dan tidak dapat berdiri sendiri dan keterlibatan semua elemen di RS sangat diperlukan dalam penerapan budaya KP (Hudson, 1999; Jeff, Law \& Baker, 2007; Reilling, 2006). Program pemberdayaan champion dapat meningkatkan peran serta seluruh elemen di RS khususnya elemen mayoritas yaitu perawat pelaksana.

\section{PENUTUP}

\section{KESIMPULAN}

Dari berbagai artikel penelitian yang dalam pembahasan maka dapat disimpukan bahwa budaya keselamatan pasien sangat terkait dengan kejadian insiden keselamatan pasien. Dengan 
meningkatnya budaya keselamatan pasien maka angka kejadian insiden keselamatan pasien dapat diminimalkan. Salah satu upaya yang dapat dilakukan untuk meningkatkan penerapan budaya keselamatan pasien untuk meminimalkan insiden keselamatan pasien adalah dengan melakukan pelaporan insiden keselamatan pasien. Namun, masih banyak praktisi keperawatan yang mengabaiakan pelaporan insiden karena menganggap insiden tersebut masih bisa ditangani dengan sendirinya atau mereka tidak melaporkan jika tidak terjadi cedera pada pasien dan hanya melaporkan jika sudah terjadi cedera. Oleh karena itu, kesadaran tentang budaya keselamatan pasien masih perlu ditingkatkan. Salah satunya dengan memberikan pelatihan-pelatihan dan mengupdate pengetahuan tentang keselamatan pasien.

\section{SARAN}

Perawat dan dokter perlu meningkatkan kesadaran akan pentingnya peran mereka dalam meningkatkan budaya keselamatan pasien. Masing masing harus bertanggungjawab memberikan pelayanan yang aman dan berkualitas. Dalam melakukan setiap prosedur dan intervensi kepada pasien harus sesuai dengan standar keamanan yang berlaku. Perawat dan dokter harus mendukung setiap program keselamatan pasien, meningkatkan pengetahuan dan keterampilan dengan mengikuti pelatihan, melaporkan setiap insiden atau kesalahan agar dapat dijadikan pembelajaran bagi pekerja lainnya.

\section{DAFTAR PUSTAKA}

Anggraeni, Dwi. 2016. Pengaruh Budaya Keselamatan Pasien terhadap Sikap Melaporkan Insiden pada Perawat di Instalasi Rawat Inap Rumah Sakit Tk. II dr. Soepraoen. Jurnal Aplikasi Manajemen, 14(2).

Arini, Diyah., Yuliastuti, Christina., Ito, Rofina, Lusia, Jawa. 2019. Hubungan Tingkat Pengetahuan Perawat tentang Identifikasi dalam Patient Safety dengan Pelaksanaannya di Ruang Rawat Inap RSUD SK. Lerik Kupang. Jurnal Ilmiah Keperawatan Stikes Hang Tuah Surabaya, 14(2).

Ezdha, Awaliyah, Ulfah, Ayudytha., Anggreini, Silvia, Nora. Fitri, Dwi, Elka. 2018. PENGARUH PELATIHAN KESELAMATAN PASIEN DENGAN METODE CERAMAH TERHADAP PEMAHAMAN PERAWAT MENGENAI PENERAPAN SASARAN KESELAMATAN PASIEN DI RS PMC PEKANBARU. Health Care : Jurnal Kesehatan, 7(2).

Herawati, Yennike, Tri. 2015. BUDAYA KESELAMATAN PASIEN DI RUANG RAWAT INAP RUMAH SAKIT X KABUPATEN JEMBER. Jurnal IKESMA , 11(1).

Mudayana, Ahmad, Ahid. 2014. PERAN ASPEK ETIKA TENAGA MEDIS DALAM PENERAPAN BUDAYA KESELAMATAN PASIEN DI RUMAH SAKIT. Supplemen Majalah Kedokteran Andalas,37(1).

Najijah. 2018. BUDAYA KESELAMATAN PASIEN DAN INSIDEN KESELAMATAN PASIEN DI RUMAH SAKIT: LITERATURE REVIEW. Journal of Islamic Nursing, 3(1). 
Peranginangin, Mori. Susilaningsih, Sri. Somantri, Irman. PERSEPSI PERAWAT DAN DOKTER TERHADAP PENERAPAN BUDAYA KESELAMATAN PASIEN DI RUMAH SAKIT ADVENT BANDUNG. Jurnal Skolastik Keperawatan,4(1).

Simamora, R. H. (2018). Buku ajar keselamatan pasien melalui timbang terima pasien berbasis komunikasi efektif: SBAR. Medan: USUpress.

Simamora, R. H. (2020). Learning of Patient Identification in Patient Safety Programs Through Clinical Preceptor Models. Medico Legal Update, 20(3), 553-556.

Suci, Wice, Purwani. 2018. PENINGKATAN BUDAYA KESELAMATAN PASIEN MELALUI PEMBERDAYAAN CHAMPION KESELAMATAN PASIEN. $J K H, 2(2)$.

Yarnita, Yeni. 2018. ANALISIS HUBUNGAN SIKAP PERAWAT DENGAN BUDAYA KESELAMATAN PASIEN DI RUANG RAWAT INAP RSUD ARIFIN ACHMAD PROVINSI RIAU. Jurnal Photon, 8(2).

Yulia, Sri., Hamid, Achir, Yani, S., Mustikasari. 2012. Peningkatan Pemahaman Perawat Pelaksana Dalam Penerapan Keselamatan Pasien Melalui Pelatihan Keselamatan Pasien. Jurnal Keperawatan Indonesia, 15(3). 